\title{
University and Practice - Cooperation in Research and Science: Case study of the Slovak University of Agriculture in Nitra
}

\author{
DOI: 10.12776/QIP.V23I1.1168
}

Jana Jarábková, Marcela Chreneková, Ol'ga Roháčiková

Received: 24 September 2018 Accepted: 24 January 2019 Published: 31 March 2019

\begin{abstract}
Purpose: Besides their educational and research functions, universities are currently essential for dissemination of knowledge in innovation processes, thus affecting the economic and social development of their environments. The formalized cooperation of the Slovak University of Agriculture (SUA) in Nitra and its partners in research and science was examined in this context.
\end{abstract}

Methodology/Approach: Formal cooperation of the university with working life partners in terms of their sectoral and geographic affiliation was analyzed in the paper. The Central Register of Contracts and the SUA Internal Register of Contracts were used as principal sources of data. Based on interviews and selected studies conducted in the Slovak Republic we further focused on identification of barriers to the transfer of the results of research into practice.

Findings: The paper confirmed cognitive and spatial proximity between SUA and its partners. The sectoral focus of the partners is closely related to the profile of the university. From the spatial point of view, more significant concentration of SUA partners in the region of Western Slovakia was confirmed. We identified several barriers to the transfer of the results of scientific research activities from the university environment into practical life.

Research Limitation/implication: We conducted research on the example of one university, thus it is not possible to generalize the results.

Originality/Value of paper: The paper analyzes the collaboration of the University in science and research with partners in practical life and identifies weaknesses and barriers to this cooperation.

Category: Case study

Keywords: cooperation; university; practice; research; innovative ecosystem 


\section{INTRODUCTION}

In addition to the role of education and research, a university plays an important role in knowledge dissemination within the innovation process and thus influences the economic and social development of the territory.

The concept of an innovation ecosystem has emerged in works of authors exploring the innovative environment at both macroeconomic and microeconomic level (Oh et al., 2016). Jackson (2011) defines an innovation ecosystem as a network of complex relationships formed between actors or institutions to enable innovation development.

Various types of innovation ecosystems can be identified: the regional innovation ecosystem (Hudec, 2007; Žitek, Klimova and Kralova, 2016) urban innovation ecosystem (Cohen, Almirall and Chesbrough, 2016), the university innovation ecosystem (Graham, 2013) etc.

Following the institutional approach to regional development, the university innovation ecosystem can be decomposed into the following elements: internal formal rules, internal human resources (students, researchers, transfer centre staff, academic entrepreneurs), external actors, relations between system actors and material resources of the system.

The assumption that innovations arise from cooperation between universities, businesses and government (Etzkowitz and Leydesdorff, 2000), represented by actors at different territorial levels, is a basis of so called Triple helix concept (model). The model presents the roles that individual actors play in the innovation process: government's role is policy making and innovation support, funding and advice; universities carry out research and development, establish and support incubators and spin-off firms. Businesses apply innovations in practice - develop products and services. Several scientific papers stress the need to complement the Triple helix model with a group of civil society actors (Lindberg, Lindgren and Packendorff, 2014) who perform the role of intermediaries (Brannback et al, 2008; Cornett, 2009). The model is referred to as the Quadruple helix.

Universities play a key role in the Quadruple helix cooperation. Importance of collaboration between a university and working life partners in innovation is emphasized (Drejer and Østergaard, 2014). The main reason of universities' involvement in such cooperation is the possibility to participate in solutions of real life challenges (Ramos-Vielba, Sánchez-Barrioluengo and Woolley, 2016). Networking with the quadruple helix partners helps in developing a community that provides learning environment for students (Hakkarainen et al., 2004) using combination of science-based knowledge and experience-based learning (Jensen et al., 2007) and brings an opportunity to obtain means for further research and education activities. Firms with strong relationships with universities have more patents and lower costs for internal research and development than businesses with no such relationships (George, Zahra and Wood, 2002), gains in 
productivity and innovation with greater novelty (Hanel and St-Pierre, 2006; Damvad, 2012) and higher revenues from new or improved products (Lööf and Broström, 2008; Mura and Rózsa, 2013; Yu and Lee, 2016). The intention of the governance and decision-making policy authorities is to operate looking for consensus and the best solutions. This can be effectively conducted only in cooperation with the other segments of quadruple helix.

The natural purpose of a university innovation ecosystem should not only be the creation of new knowledge but also its transfer. Technology transfer includes direct or indirect transmission of scientific knowledge to real life (Brennenraedts, Bekkers and Verspagen, 2006). However, a linear model of technology transfer is no longer sufficient to account for the nuances and complexities of the process. Shortcomings of the traditional linear model of technology transfer include strict linearity and oversimplification, a one-size-fits-all approach, overemphasis on patents etc. (Bradley, Hayter and Link, 2013). It is necessary to include informal mechanisms of technology transfer, for example building entrepreneurial (Hayter, Lubynsky and Maroulis, 2017) and organizational culture (Boh, DeHaan and Strom, 2016), university reward system, developing cognitive and social proximity with work-life partners etc. A model of the transfer can have sectoral specific nuances (Genet, Errabi and Gauthier, 2012). Several studies identified barriers related to the transfer of scientific and research activities into practice (Davey, Rossano and Van der Sijde, 2016).

Different dimensions (geographic, institutional, organisation, cognitive, social) of proximity to partners play different roles in the cooperation. Economic geographers put emphasis on economic advantages of being co-located (Boh, DeHaan and Strom, 2016; Balland, Boschma and Frenken, 2015). Geographic proximity to public knowledge institutions is generally important for firms' likelihood for innovation collaboration (Broström, 2010; Laursen, Reichstein and Salter, 2011). However, the proximity is sectoral specific. In some sectors it is less than 10 kilometers, in other sectors it is more or the co-location does not play a role (Abramovsky and Simpson, 2011). Actors of cooperation need also cognitive proximity in terms of a knowledge base in order to communicate, understand, absorb and process new information successfully (Noteboom, 2000). The innovation process requires coordinated effective mechanisms to transfer complementary pieces of knowledge between agents. Organizational, social, institutional and geographical proximity may, each in its own way, but most likely in combination, provide solutions to this problem of coordination (Boshma, 2005; Boh, De-Haan and Strom, 2016).

Davey, Rossano and Van der Sijde (2016) identified several barriers related to the transfer of scientific and research activities into practice as: lack of information on a suitable partner, lack of finance (Yencken and Ralston, 2005). The third barrier is cultural, social and economic differences in academic and business environment (Bruneel, D'Este and Salter, 2010). The differences reflect different time and market orientation. Universities strive to make progress in their own interests and use their own methods of validation and rewarding, while 
entrepreneurs are more focused on practical aspects, profits and commercial results (Bruneel, D’Este and Salter, 2010; Lopez-Martinez et al., 1994), which leads to different expectations. Bureaucracy is considered the gravest problem of academic environment. The fourth barrier is the application of scientific and research results. Universities are aimed at dissemination of results and publishing, while business want to be owners and sometimes even hold some results secret as a part of the competitiveness strategy. The issue of intellectual property is also debated. Universities consider intellectual property as something more than a source of income; it is rather a progress in knowledge. They want to publish results before they are protected and do not want to guarantee exclusivity of results. On the other hand, businesses are limited by their absorption capacity (Bekkers and Bodas-Freitas, 2010) and the scale of knowledge. Small and medium enterprises face high transaction costs (Reinhard and Schmalholz 1996).

\section{METHODOLOGY}

The objective of the paper is to examine the level and character of cooperation between the Slovak University of Agriculture in Nitra (hereinafter referred to as SUA) and partners from the praxis and to identify the barriers limiting a closer cooperation between the university and partners in the field of research and technology transfer.

Based on published information as well as personal experience, we assume that the SUA cooperates in the field of science and research with the external environment. In order to get more detailed information on the level, the focus of this cooperation and in order to identify the cooperating partners, we ask the following questions in the article: Who are the SUA partners in science and research cooperation (in terms of their geographical and sectoral relevance)? Does the SUA mainly cooperate with partners who are close to its sectoral focus (cognitive proximity)? Does the SUA work more closely with partners closer to the site? What is the purpose of this cooperation specifically? Are there any obstacles to cooperation between SUA and their working life partners? If so, what kind of obstacles?

The paper is focused on the formal cooperation of the university and its faculties, objectively published by the Central register of contracts of the Slovak Republic (available at https://www.crz.gov.sk/) and internal records on contractual agreements of SUA. The contracts were evaluated in the period of six years (2011 to 2016) and were focused on the cooperation in the field of applied research, participation in research activities, networking and partnership building, transfer of finance in favor of science and research, common education for $\mathrm{PhD}$ students and providing opportunities for practical training for students.

The paper classifies the goals of cooperation as follows. Applied research is understood as creating conditions for the future and current research at SUA, establishment of common facilities for applied research in cooperation with 
partners using research results in praxis. Transfer of resources means the transfer of finance to support research and scientific activities of SUA (non-repayable funds financing infrastructure important for research and science, financial support for research projects from agencies, donations from businesses etc.).Provision of services represents a wide scale of services in favor of partners, though it needs to be added that such relations are bilateral, i.e. a university is a service provider (e.g. consultancy, counselling, experiments, tests, measurements, analyses etc.) as well as a customer (expert services provided by specialized data acquisition for research etc.).

Co-investigation of a research means a cooperation of two or more partners in investigating a common research. It is usually agreed in cooperation contracts. Practical training for students is carried out based on a contract between a university and a partner on practical training of students and represents an immediate confrontation of knowledge from a university with practice. The type of cooperation also covers networking of partners (predominantly universities and businesses) aimed at connecting theory and practice. Networking and building partnerships includes activities building preconditions for a future cooperation in the field of research, development, innovation or technology transfer. $\mathrm{PhD}$ education means providing a $\mathrm{PhD}$ study in cooperation with a partner organisation based on a written contract.

Based on the selected contracts (590) we identified partners (319) cooperating with SUA in referred activities in the monitored period. Prevailing types of cooperation were identified based on number of contractual relations with partner categories. The paper analyses sectoral and geographical relevancy of the partners. It is assumed that cognitive proximity and geographical proximity support each other (Fáziková and Melichová, 2014). In the final part of the paper are examined the barriers limiting the transfer of scientific and research results of SUA into praxis. The identification of barriers was performed according to selected studies (Davey, Rossano and Van der Sijde, 2016; Yencken and Ralston 2005; Bruneel, D'Este and Salter, 2010; Lopez-Martinez et al., 1994; Plewa and Quester, 2006; Jones-Evans, 1998; Bekkers and Bodas-Freitas, 2010; Reinhard and Schmalholz, 1996; Plaisier, 2010; Hanel and St-Pierre, 2006; Lööf and Broström, 2008), the study "Strengthening the Roles of Universities in Regions" (Hanová et al., 2016), processed, based on a questionnaire survey, conducted at 16 Slovak universities (67\% of all the universities in Slovakia), and 18 interviews with the SUA management and employees carried out in 2017.

\section{RESULTS}

The Slovak University of Agriculture was founded in 1952 (formerly called University of Agriculture in Nitra until 1996). Currently, it is composed of six faculties: Faculty of Agrobiology and Food Resources (FAFR), Faculty of Biotechnology and Food Sciences (FBFS), Faculty of Engineering (FE), Horticulture and Landscape Engineering Faculty (HLEF), Faculty of Economics 
and Management (FEM), and Faculty of European Studies and Regional Development (FESRD).

Within the scope of its scientific and research activities, SUA traditionally covers the agri-food sector functions from the perspective of production sustainability, food quality, ecology and environment and also social status of society (Report on scientific and research results of SUA in 2016). Currently, the research at SUA is focused on the following 5 fundamental themes (Chreneková et al., 2017):

1. Sustainable agriculture and climatic changes (production and breeding systems, agro technologies, food production chains and biodiversity).

2. Biotechnologies and food technologies (high-tech and genetically modified production, quality and safety of food).

3. Horticulture, landscape architecture and changes in land use (knowledgebased horticulture, landscape architecture, water management, landscape planning etc.).

4. Industrial and bioindustrial technologies (technical and technological use of renewable resources and development of new technologies for industry and agriculture in production and processing).

5. Society and economy (behavior towards legislation, development and recovery of regions, commercial chains, social entrepreneurship in agrifood industry).

Research directions of SUA facilities are interdisciplinary, covering biological, ecological, production, socio-economic, technological and technical aspects of natural resources use and addressing the current issues of agricultural production, landscape and agri-food industry.

\subsection{Forms of SUA Scientific and Research Cooperation}

Cooperation of the university in research and science is conducted on formal as well as informal bases. Formal cooperation means cooperation based on a contract, a registered form of cooperation. Informal cooperation (non-contractual cooperation) is usually based on personal contacts between partner organizations and represents a "silent" transfer of knowledge acquired by university research (Grimpe and Hussinger, 2008). Results of informal cooperation are often unexpected (Link, Siegel and Bozeman, 2007). Although informal cooperation in research and science is important e.g. as a basis for starting a formal cooperation, it is hardly explorable and definable in an exact form. Therefore, the paper is focused on examining formal cooperation of the university in research and science, particularly in the field of knowledge transfer within applied research.

Throughout the monitored period, SUA has concluded 89 of such framework contracts, the most important being the Agreement on association of scientific and technological universities in Slovakia (2013) with Comenius University in 
Bratislava, the Agreement on cooperation with Constantine the Philosopher University in Nitra and the Institute on Plant Genetics and Biotechnology (2013) starting the common research centre "AgroBioTech", and the Association Contract (2015), establishing the National Technology Transfer Centre. The Technology Transfer Centre members are the Slovak Centre of Scientific and Technical Information (CSTI), Slovak Academy of Sciences and seven Slovak universities, (SUA, Slovak University of Technology in Bratislava, Technical University of Košice, Technical University of Zvolen, Comenius University in Bratislava, Pavol Jozef Šafárik University in Košice and University of Žilina). The knowledge transfer from universities to praxis has been extensively implemented via cooperation with private sector. It is represented mainly by applied research, in some cases co-financed by businesses, mutual provision of services, and offering practical training and internships for students. Applied research is conducted based on cooperation contracts, agreements on coinvestigation and co-financing of research projects, or contracts on future contracts with specific partners aimed at application of research project results. As for applied research, the projects financed by the Slovak Research and Development Agency (SRDA) are of crucial importance. The university provides its partner especially the following services:

- preparation of studies, strategic documents for public or private partners, handbooks, opinions,

- evaluation and monitoring of projects,

- access to databases, data, information systems and devices,

- trials, measurements, testing and assessment, development and laboratory activities,

- analyses and supervision, consultancy,

- publishing of research activities.

Many businesses support research activities of the university by direct donations. Though the average financial donation to research activities reached 803 EUR, it is not negligible. The overall sum of such donations throughout the monitored period reached over 90,000 EUR.

The knowledge transfer from universities to praxis is also executed through practical training for students, field trips and internships. These are mainly based on contracts.

\subsection{Objectives of contractual cooperations}

Goals of SUA cooperation in research and science depend on contractual partners, e.g. in case of applied research, university facilities cooperate with other universities, research institutions, units of regional and local self-government, business and also NGOs. A similarly wide scope of partners is applied when a 
university provides services. When providing services, the relations are mutual; i.e. a university provides services to partners and vice versa (e.g. testing, measurements, lending equipment etc.). The preconditions for further development of research and scientific activities are built mainly through networking and partnerships with universities, research institutions and businesses, and also by providing education for new generations of researchers and offering possibilities for practical training in favor of students and graduates. Tab. 1 provides information on objectives of contractual cooperation between SUA and various types of contractual partners in 2011-2016. The data express intensity of cooperation with the particular type of entities.

Table 1 - Objectives of SUA Contractual Cooperations in Science and Research in 2011-2016 (\%) (Own Contribution Based on Internal Records of Contractual Agreements of SUA)

\begin{tabular}{|c|c|c|c|c|c|c|}
\hline & 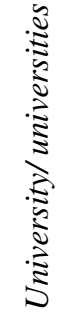 & 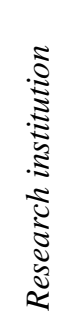 & 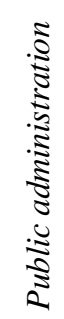 & 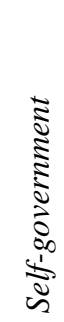 & 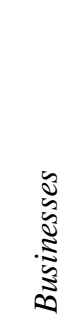 & 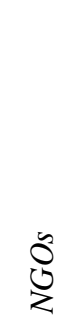 \\
\hline Applied research & 0.5 & 2.2 & 7.6 & 0.7 & 16.1 & 2.0 \\
\hline Transfer of resources & & & 0.3 & 0.3 & 20.2 & 0.5 \\
\hline Provision of services & 1.2 & 1.9 & 3.1 & 5.6 & 11.0 & 1.2 \\
\hline Co-Investigation of research projects & 1.2 & 2.4 & 0.3 & & & \\
\hline Practical training & & 0.8 & 1.0 & & 5.9 & \\
\hline Networking and partnerships & 0.8 & 5.8 & 0.2 & 0.3 & 4.2 & 1.4 \\
\hline $\mathrm{PhD}$ education & & 1.0 & & & & \\
\hline
\end{tabular}

\subsection{SUA partners}

Motivation for cooperation in research and knowledge transfer to private sector depends on the type of a partner (Belderbos, Carree and Lokshin, 2004).

Within its scientific and research activities, SUA cooperates with subjects from private, public and NGO sectors. Public subjects are represented predominantly by universities, research institutions, specialized agencies to support science and research (CSTI, SRDA), ministries and self-government (regional and local) and their cooperation with SUA is extensive. As for the intensity of cooperation, a special position belongs to the SUA University Farm owned by the university. Its main goal is to create conditions and provide services related to practical 
training, research, development and internship of students. Private subjects are domestic as well as foreign businesses active in the territory of Slovakia, cooperating on contractual bases. Non-profit sector is represented by associations, interest groups of legal persons, foundations and professional associations. The structure of contractual partners is dominated by private sector partners $(67 \%)$, followed by public sector partners $(25 \%)$ and NGOs $(8 \%)$.

\subsection{Sectoral Classification of Partners}

As for sectoral classification, SUA cooperates in research and science predominantly with subjects active in the sector of agriculture and fishing (A category, 20\%), followed by those classified to professional, scientific and technical activities ( $\mathrm{M}$ category, 15\%), manufacturing (C category, 15\%), wholesale and retail trade, repair of motor vehicles and motocycles ( $\mathrm{G}$ category, $13 \%)$, and public administration and defence; compulsory social security (O category, $10 \%)$. Intensity of cooperation and sectoral classification of partners depend on the focus of educational and research activities of the faculties and other university facilities, and also on their amount.

Based on registered contractual relations (science and research) it can be stated that by faculties, most contracts were concluded by FAFR (22\%) and FE $(16.30 \%)$. However, calculating the number of contracts per employee, small faculties (FESRD, HLEF, FE) are more active.

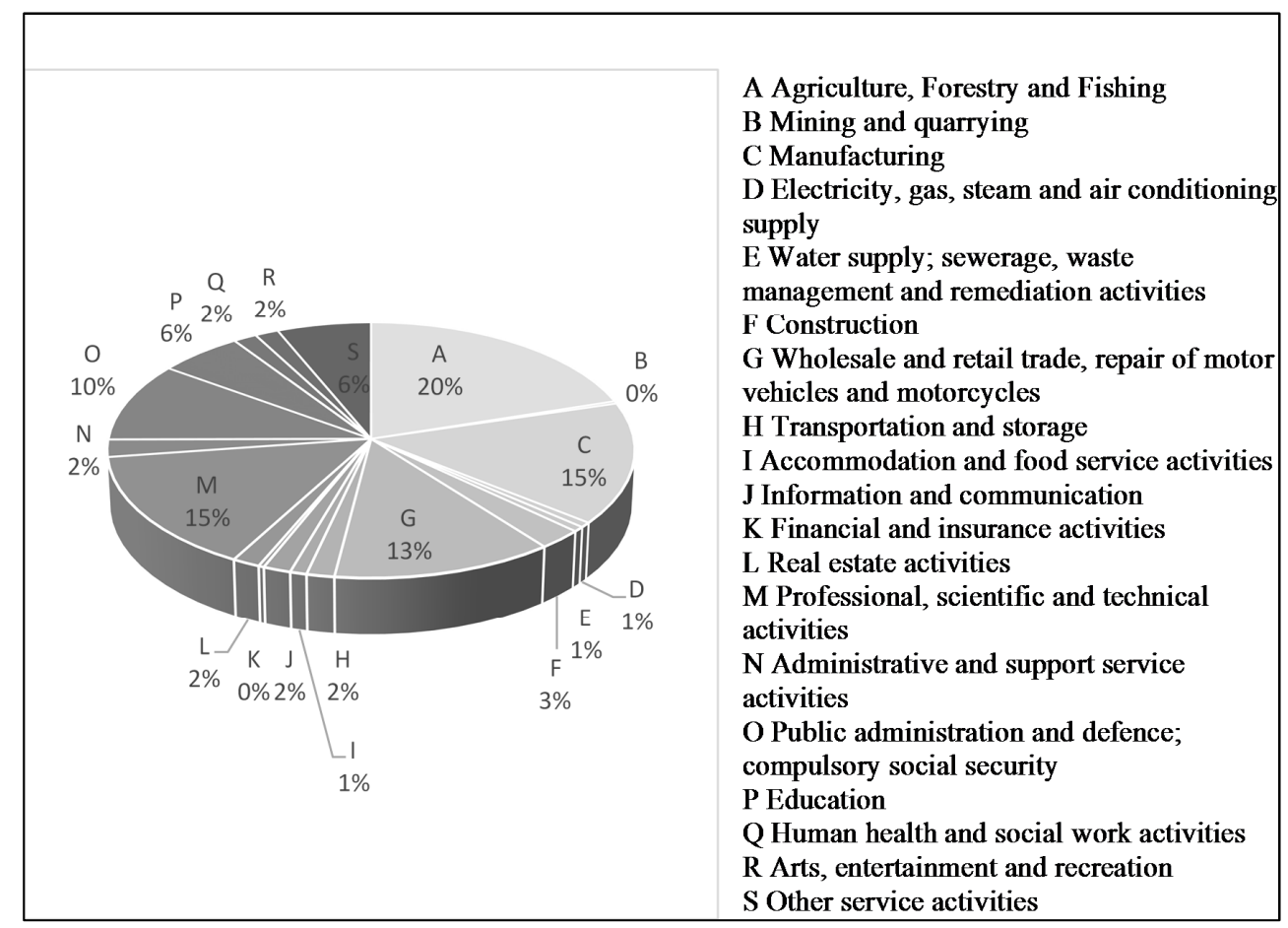

Figure 1 - Sectoral Structure of SUA Partners (2011-2016) (Own Contribution) 
While contractual partners of FAFR belong mainly to the sector of professional, scientific and technical activities (M) and agriculture (A), FE has concluded contracts predominantly with partners belonging to the sectors of manufacturing (C) and wholesale and retail trade, repair of motor vehicles and motocycles (G). The partners of HLEF, FESRD, FBFS and FEM are significantly represented by those belonging to public administration (O). The analysis confirms that all faculties cooperate with scientific and research institutions (M) and businesses and associations active in the field of agriculture (A). The sectoral structure of partners is strongly dependent on the focus of scientific activities of the faculties and their facilities.

\subsection{Spatial Aspects of Cooperation}

Spatial distribution of subjects having concluded contractual cooperation with SUA in research and science is illustrated in Fig. 2. Based on the distribution and spatial concentration it can be claimed that the university cooperates mainly with local and regional external environment (Chreneková et al., 2017). Most of the partners come from Nitra district (68.3\%). Western Slovakia partners represent $84 \%$, Central Slovakia $8.3 \%$ and Eastern Slovakia $7.5 \%$ of all cooperating entities. A relatively high number of subjects cooperating with the university on the basis of contractual relations is concentrated in Bratislava and Trnava, the two closest agglomerations. There are localized mainly academic partners, other specialized scientific and research institutions and in case of Bratislava also public sector subjects. Nevertheless, in the case of local and regional external environment, there are mainly partners - business subjects of diverse focus and public sector representatives at local and regional level, mainly municipalities and their budgetary or subsidized organizations, located not only in district centres of the Nitra County but also in municipalities situated close to Nitra, the seat of the university. Based on the findings, it is presumed that the innovative ecosystem of the university affects local and regional development, and geographical proximity is significant when considering the transfer of research and science results and knowledge spill-overs from the university to society as a whole. 


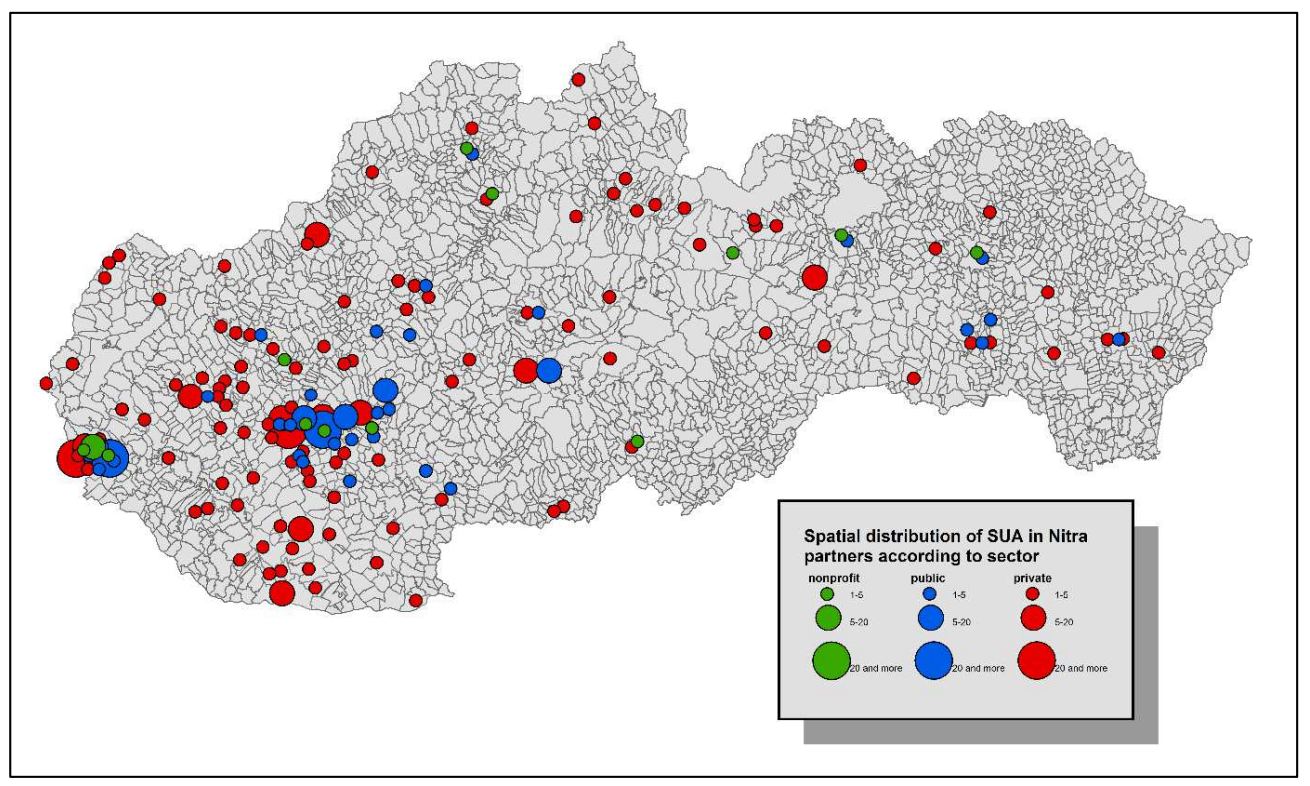

Figure 2 - Spatial Distribution of SUA Partners according to Sectoral Classification (Own Contribution)

As it is clear from controlled interviews with innovative ecosystem agents, research activities aimed at practice are to a great extent still conducted informally, based on personal contacts. The majority of subjects cooperating with the university in research is located in the counties of the Western Slovakia. The subjects located at a greater distance to the university (Northern and Eastern Slovakia) are mostly agricultural enterprises; it is presumed that their relations with the university are based on cognitive and social proximity.

\subsection{Barriers Limiting Cooperation of Slovak Universities with Business Subjects and Other Agents of Regional Development}

Identification of barriers to cooperation relations of Slovak universities with working life partners was performed. Generally, the barriers were recognized according to 11 selected studies (listed in the Methodology). In barriers identified in 16 Slovak universities resulted study "Strengthening the Roles of Universities in Regions" of Hanová et al. (2016).

In the context of the identified barriers limiting cooperation between universities and business subjects and especially the transfer of scientific and research results from academic to business environment it can be stated that situation in Slovakia is quite similar in many aspects. The study "Strengthening the roles of universities in regions" (Hanová et al., 2016) summarized the main barriers and opportunities of cooperation between universities and businesses as well as other agents of regional development in Slovakia (quoted parts of the following text correspond with results of the study). The study results confirmed that Slovak 
universities also face the information and communication barrier - "when cooperating with practitioners, universities lack sufficient information, using adhoc systems"; "the academic environment is specific, conservative, complicated and intransparent from the perspective of business and public administration subjects, which causes communication problems and limits more effective cooperation"; "the common platform for the discussion on research projects and needs of regions and practitioners does not exists". The lack of resources and not only financial ones is another barrier of cooperation. "Universities are dependent primarily on public subventions, as no other financial mechanisms are customary in Slovakia"; "insufficient capacities (lack of finance, administrative and bureaucratic burdens, subsequent lack of time) of universities to carry out activities focused on fulfilling their missions". The above mentioned differences in academic and business environments limit the mutual cooperation. This results into university employees cooperating with external environment on individual bases.

\subsection{Barriers Limiting Cooperation between SUA and Businesses and Other Practitioners}

Cooperation barriers specific for SUA were analyzed and proven within 18 interviews with the SUA management and employees of research related units. Positions of interviewees are as follows: vice-rector for development, vice-rector for research, deans of faculties, director of the AgroBioTech research centre, head of the university Transfer Centre, head of the Expert Institute (of SUA), 3 seniors - members of former university management, representatives of 3 cooperating firms (quoted parts of the following text are statements of them).

Barriers limiting cooperation between SUA and businesses and other practitioners were identified based on controlled interviews with managers of SUA at the university level as well as at faculty levels. The interviews showed that practitioners often "cannot define a research or development issue or they have specific demands which they cannot put into context". On the other hand, "the university is often not familiar with demands of practitioners and does not seek them actively". Many businesses interested in cooperation with universities "do not appreciate results springing up in academic environment", and they have a mistaken belief that "as universities are financed from public resources, their know-how should be distributed free of charge". The interviews proved that the university is well-equipped from the perspective of human resources and material resources, but the disinterest of businesses in cooperation is a crucial barrier for the transfer of scientific and research activities into practice. "Cooperation in our sectors is often endangered by existential problems the businesses have to deal with." In their struggle to "survive", the businesses minimize their research and development costs. Moreover, the state does not create a legislation motivating agricultural businesses to increase quality of their products for instance. Such legislation would encourage the cooperation of agricultural enterprises and the university. Another problem is "lack of enterprises' confidence in research 
results. The enterprises often adhere to their traditional procedures and they are not willing to adopt new ones".

The interviews also disclosed that even though the university has been making individual steps towards the support for knowledge transfer of research and science results into practice (e.g. adopting the Directive no. 4/2017 on Protection and Administration of Intellectual Property Rights at SUA), there is no complex internal system supporting the transfer of knowledge into practice.

Formal cooperation in research and science at the university often results from informal, personal relations between SUA employees and practitioners. Therefore, it is desirable that employees are encouraged towards both formal and informal cooperation with practice. The interviews also reflected criticism regarding the conditions for supporting entrepreneurial activities at the university. "The conditions are not motivational". Some faculties have their own support systems for cooperation with practitioners, motivating their employees to building more intensive and formalized relations with practitioners. One of the possible solutions is a reward scheme.

SUA employees (as well as employees of other Slovak universities) find also problematic that "results for practice are undervalued compared to publication and project results". Although they are equally demanding (from the perspective of time, qualification, material and technological requirements) as publications or projects, in light of accreditation criteria they are irrelevant. Due to the stated reasons, academicians are primarily focused on publications in scientific journals accepted by scientists (scientific journals with impact factors, scientific monographs etc. published in English in particular), which are not available to ordinary practical users or their highly professional language is hardly understandable to the public.

The use of university facilities' potential in favor of the university itself is an interesting idea mentioned in the interviews. Some research and scientific results are applicable directly in the university environment. The university uses the potential for transfer of knowledge acquired through its scientific and research activities within its environment to a limited extent only (direct awards, application of theses results in the university environment, accepting new ideas of employees etc.). "Why the university itself wouldn't be the lab?"

\section{CONCLUSION}

The role of universities in innovation processes is unsubstitutable. University is one of the key elements of the Triple helix model. In the model, a university executes research activities in the first place, and supports businesses that enable the transfer of new knowledge from academic environment to praxis (incubators, start ups) or valorize the results of research activities (spin-off). To fulfil these tasks, a university shall cooperate with partners of similar areas of interest (cognitive proximity). This was confirmed in orientation of SUA partners. The 
university covers several areas of research, particularly biological, ecological, productive, socio-economic, technological and technical aspects of natural resources use and current issues of agricultural production, landscape and agrifood industry. Its research partners are primarily from the fields of agriculture, professional and scientific activities (research institutions) and manufacturing; these represent $50 \%$ of SUA contractual cooperations. The focus of contractual cooperation differs according to faculties and their research activities. The faculties focused on social sciences (FEM, FESRD) also cooperate with public administration bodies. The faculties focused on natural sciences (FAFR, FBFS) cooperate mainly with agricultural subjects and related research institutions, and the technical faculty (FE) concludes cooperation contracts with subjects focused on manufacturing and follow-up activities. There is a significant share of private sector on overall contracts of SUA (67\%). The objects of cooperation in research and science are applied research, provision of services by the university, networking, building partnerships, mutual education of young scientists and students in cooperation with research institutions, and organization of practical trainings for students in cooperation with business subjects. From the spatial perspective, the university cooperates predominantly with subjects from the local and regional external environment. SUA partners are concentrated in the Western Slovakia (84\% of all cooperating entities). In other regions of Slovakia, SUA cooperates mainly with agricultural enterprises. Even though authors agree on the statements "the scientific potential of universities is large" and "the cooperation between academic environment and business practitioners is inevitable", the transfer of scientific results from academic environment to businesses comes across many barriers. The conducted research stresses information barriers (communication problems), financial problems and motivations to transfer knowledge to practice, and barriers issuing from the differences between the two environments, including the different approaches to utilization of research results. Hanová et al. (2016) claim the level of cooperation between academic and business environments depends on economic levels of countries. We agree with the idea that "the cooperation in advanced countries with knowledge economy applied functions usually on the pull principle, with businesses extensively looking for new results of scientific and research activities of universities. However, in Slovakia (and also in other EU countries), this approach is replaced by the push effect, with universities and research institutions striving to enforce and apply their research results in praxis". The interviews imply that it is crucial to intensify the communication with practitioners (inform them on possibilities of the university, search for common research issues), encourage businesses to cooperate with the university, set up conditions for the support of knowledge transfer at the university in a motivational, rewarding way, and appreciate the published results devoted to practitioners in evaluation criteria of the university and its employees. 


\section{ACKNOWLEDGEMENTS}

The contribution was prepared under the UNIREG project (Universities and economic development of regions) No. APVV-14-0512.

\section{REFERENCES}

Abramovsky, L. and Simpson, H., 2011. Geographic proximity and firmuniversity innovation linkages: evidence from Great Britain. Journal of economic geography, 11(6), pp.949-977. https://doi.org/10.1093/jeg/lbq052.

Balland, P.A., Boschma, R. and Frenken, K., 2015. Proximity and innovation: From statics to dynamics. Regional Studies, 49(6), pp.907-920. https://doi.org/10.1080/00343404.2014.883598.

Bekkers, R. and Bodas-Freitas, I., 2010. Catalysts and barriers: Factors that affect th performance of university-industry collaborations. In: Aalborg University, $13^{\text {th }}$ International Schumpeter Society Conference 2010 on Innovation, Organisation, Sustainability and Crises. Aalborg, Denmark, 21-24 June 2010. Aalborg: Aalborg University.

Belderbos, R., Carree, M. and Lokshin, B., 2004. Cooperative R\&D and firm performance. Research policy, 33(10), pp.1477-1492. https://doi.org/10.1016/j.respol.2004.07.003.

Boh, W.F., De-Haan, U. and Strom, R., 2016. University technology transfer through entrepreneurship: faculty and students in spin-offs. The Journal of Technology Transfer, 41(4), pp.661-669. https://doi.org/10.1007/s10961-0159399-6.

Boschma, R., 2005. Proximity and innovation: a critical assessment. Regional studies, 39(1), pp.61-74. https://doi.org/10.1080/0034340052000320887.

Bradley, S.R., Hayter, C.S. and Link, A.N., 2013. Models and methods of university technology transfer. Foundations and Trends ${ }^{\circledR}$ in Entrepreneurship, 9(6), pp.571-650. http://dx.doi.org/10.1561/0300000048.

Brannback, M., Carsrud, A., Krueger ${ }^{\mathrm{Jr}}$, N. and Elfving, J., 2008. Challenging the triplehelix model of regional innovation systems: a venture-centric model. International Journal of Techno entrepreneurship, 1(3), pp.257-277. DOI: 10.1504/IJTE.2008.020539.

Brennenraedts, R., Bekkers, R. and Verspagen, B., 2006. The different channels of university-industry knowledge transfer: Empirical evidence from Biomedical Engineering. [Working Paper 06.04] Eindhoven: Eindhoven Centre for Innovation Studies.

Broström, A., 2010. Working with distant researchers - Distance and content in university-industry interaction. Research Policy, 39(10), pp.1311-1320. https://doi.org/10.1016/j.respol.2010.09.002. 
Bruneel, J., D'Este, P. and Salter, A., 2010. Investigating the factors that diminish the barriers to university-industry collaboration. Research policy, 39(7), pp.858-868. https://doi.org/10.1016/j.respol.2010.03.006.

Central Register of Contracts of the Slovak Republic, 2019. Central Register of Contracts of the Slovak Republic. [online] Available: <https://www.crz.gov.sk/> [Accessed 03 March 2019].

Chreneková, M., Melichová, K., Hrivnák, M. and Jarábková, J., 2017. Inovačný ekosystém Slovenskej pol'nohospodárskej univerzity a jej spolupráca s praxou. In: Klímová, V and Žítek, V., $20^{\text {th }}$ International Colloquium on Regional Sciences. Conference Proceedings. Kurdějov, Czech Republic, 14-16 June 2017. Brno: Masarykova univerzita. https://doi.org/10.5817/CZ.MUNI.P210-85872017-32.

Cohen, B., Almirall, E. and Chesbrough, H., 2016. The city as a lab: open innovation meets the collaborative economy. California Management Review, 59(1), pp.5-13. https://doi.org/10.1177/0008125616683951.

Cornett, A.P., 2009. Aims and strategies in regional innovation and growth policy: A Danish perspective. Entrepreneurship and Regional Development, 21(4), pp.399-420. https://doi.org/10.1080/08985620903020078.

Damvad, 2012. Measuring the Economic Effects of Companies Collaborating with the University of Copenhagen. Copenhagen: Damvad.

Davey, T., Rossano, S. and Van der Sijde, P., 2016. Does context matter in academic entrepreneurship? The role of barriers and drivers in the regional and national context. The Journal of Technology Transfer, 41(6), pp.1457-1482. https://doi.org/10.1007/s10961-015-9450-7.

Drejer, I. and Østergaard, C.R., 2014. The role of geographical, cognitive and social proximity in university-industry collaboration on innovation. In: Centre for Innovation Research, IRIS and University of Stavanger, $9^{\text {th }}$ Regional Innovation Policy Conference. Stavanger, Norway, 16-17 October 2014. Stavanger, Norway: University of Stavanger.

Etzkowitz, H. and Leydesdorff, L., 2000. The dynamics of innovation: from National Systems and "Mode 2" to a Triple Helix of university-industrygovernment relations. Research policy, 29(2), pp.109-123. https://doi.org/10.1016/S0048-7333(99)00055-4.

Fáziková, M. and Melichová, K., 2014. The Problems of Knowledge Economy and Innovation Processes in Agriculture Case Study of the Nitra Region. Acta Regionalia et Environmentalica, 11(1), pp.24-29. https://doi.org/10.2478/aree2014-0005. 
Genet, C., Errabi, K. and Gauthier, C., 2012. Which model of technology transfer for nanotechnology? A comparison with biotech and microelectronics. Technovation, 32(3), pp.205-215. https://doi.org/10.1016/j.technovation.2011.10.007.

George, G., Zahra, S.A. and Wood, D.R., 2002. The effects of businessuniversity alliances on innovative output and financial performance: a study of publicly traded biotechnology companies. Journal of Business Venturing, 17(6), pp.577-609. https://doi.org/10.1016/S0883-9026(01)00069-6.

Graham, R., 2013. Technology innovation ecosystem benchmarking study: key findings from phase 1. Cambridge: MIT Skoltech Initiative.

Grimpe, C. and Hussinger, K., 2008. Formal and informal technology transfer from academia to industry: complementarity effects and innovation performance [Discussion Paper No. 08-080]. Mannheim: ZEW - Leibniz Centre for European Economic Research.

Hakkarainen, K.P., Palonen, T., Paavola, S. and Lehtinen, E., 2004. Communities of networked expertise: Professional and educational perspectives. Amsterdam: Elsevier Science.

Hanel, P. and St-Pierre, M., 2006. Industry-university collaboration by Canadian manufacturing firms. The Journal of Technology Transfer, 31(4), pp.485-499. https://doi.org/10.1007/s10961-006-0009-5.

Hanová, M., Moravčíková, D., Rehák, Š and Vozár, L., 2016. Posilnenie úlohy vysokých škôl v regiónoch. Bratislava: Ministerstvo školstva, vedy, výskumu a športu Slovenskej republiky.

Hayter, C.S., Lubynsky, R. and Maroulis, S., 2017. Who is the academic entrepreneur? The role of graduate students in the development of university spin-offs. The Journal of Technology Transfer, 42(6), pp.1237-1254. https://doi.org/10.1007/s10961-016-9470-y.

Hudec, O., 2007. Regionálne inovačné systémy: Strategické plánovanie a prognózovanie. Košice: Technická univerzita v Košiciach.

Jackson, B.D.J., 2011. What is an innovation ecosystem?. [pdf] Washington, DC. Available at: <http://erc-assoc.org/sites/default/files/downloadfiles/DJackson_What-is-an-Innovation-Ecosystem.pdf $>$ [Accessed 03 March 2019].

Jensen, M.B., Johnson, B., Lorenz, E. and Lundvall, B.Å., 2007. Forms of knowledge and modes of innovation. Research Policy, 36(5), pp.680-693. https://doi.org/10.1016/j.respol.2007.01.006. 
Jones-Evans, D., 1998. Universities, technology transfer and spin-off activities: Academic entrepreneurship in different European regions. [pdf] European Union, Glamorgan: University of Glamorgan Business School. Available at: $<$ https://cordis.europa.eu/docs/publications/7864/78645511-6_en.pdf > [Accessed 03 March 2019].

Laursen, K., Reichstein, T. and Salter, A., 2011. Exploring the effect of geographical proximity and university quality on university-industry collaboration in the United Kingdom. Regional studies, 45(4), pp.507-523. https://doi.org/10.1080/00343400903401618.

Lindberg, M., Lindgren, M. and Packendorff, J., 2014. Quadruple Helix as a way to bridge the gende gap in entrepreneurship: the case of an innovation system project in the Baltic Sea region. Journal of the Knowledge Economy, 5(1), pp.94113. https://doi.org/10.1007/s13132-012-0098-3.

Link, A.N., Siegel, D.S. and Bozeman, B., 2007. An empirical analysis of the propensity of academics to engage in informal university technology transfer. Industrial and corporate change, 16(4), pp.641-655. https://doi.org/10.1093/icc/dtm020.

Lööf, H. and Broström, A., 2008. Does knowledge diffusion between university and industry increase innovativeness?. The Journal of Technology Transfer, 33(1), pp.73-90. https://doi.org/10.1007/s10961-006-9001-3.

López-Martínez, R.E., Medellin, E., Scanlon and Solleiro, J.L., 1994. Motivations and obstacles to university industry cooperation (UIC): a Mexican case. R\&D Management, 24(1), pp.017-030. https://doi.org/10.1111/j.14679310.1994.tb00844.x.

Mura, L. and Rózsa, Z., 2013. The impact of networking on the innovation performance of SMEs. In: Löster, T. and Pavelka, T., The $7^{\text {th }}$ International Days of Statistics and Economics: Conference Proceedings. Prague, Czech Republic, 19-21 September 2013. Slaný: MELANDRIUM.

Noteboom, B., 2000. Learning and Innovation in Organizations and Economies. Oxford: Oxford University Press.

Oh, D.S., Phillips, F., Park, S. and Lee, E., 2016. Innovation ecosystems: A critical examination. Technovation, 54(C), pp.1-6. https://doi.org/10.1016/j.technovation.2016.02.004.

Plaisier, H., 2010. Triple Helix Cooperation in the Rotterdam Region. Bachelor Thesis. Erasmus Universiteit Rotterdam.

Plewa, C. and Quester, P., 2006. The effect of a university's market orientation on the industry partner's relationship perception and satisfaction. International Journal of Technology Intelligence and Planning, 2(2), pp.160-177. https://doi.org/10.1504/IJTIP.2006.011306. 
Ramos-Vielba, I., Sánchez-Barrioluengo, M. and Woolley, R., 2016. Scientific research groups' cooperation with firms and government agencies: motivations and barriers. The Journal of Technology Transfer, 41(3), pp.558-585. https://doi.org/10.1007/s10961-015-9429-4.

Reinhard, M. and Schmalholz, H., 1996. Technologie transfer in DeutschlandStand und Reformbedarf. Berlin: Duncker \& Humblot.

Yencken, J. and Ralston, L., 2005. Evaluation of incentives for commercialization of research in Australian universities. A survey of selected Australian universities. Canberra: Commonwealth of Australia.

Yu, G.J. and Lee, J., 2016. When should a firm collaborate with research organizations for innovation performance? The moderating role of innovation orientation, size, and age. The Journal of Technology Transfer, 42(6), pp.14511465. https://doi.org/10.1007/s10961-016-9469-4.

Žítek, V., Klimova, V. and Kralova, M., 2016. Assessment of regional innovation systems as anassumption for innovation policy adjustment. Transylvanian Review of Administrative Sciences, 12(49), pp.169-186.

\section{ABOUT AUTHORS}

Jana Jarábková - doc. Ing. PhD., Department of Regional and Rural Development, Faculty of European Studies and Regional Development, SUA - Slovak University of Agriculture in Nitra, Tr. A. Hlinku 2, 94976 Nitra, Slovak Republic. E-mail: jana.jarabkova@uniag.sk.

Marcela Chreneková - Ing. PhD., Department of Regional and Rural Development, Faculty of European Studies and Regional Development, SUA - Slovak University of Agriculture in Nitra, Tr. A. Hlinku 2, 94976 Nitra, Slovak Republic. E-mail: marcela.chrenekova@uniag.sk.

Ol'ga Roháčiková - doc. Ing. PhD., Department of Public Administration, Faculty of European Studies and Regional Development, SUA - Slovak University of Agriculture in Nitra, Tr. A. Hlinku 2, 94976 Nitra, Slovak Republic. E-mail: olga.rohacikova@uniag.sk.

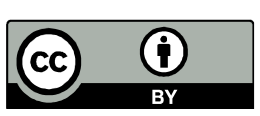

(C) 2019 by the authors. Submitted for possible open access publication under the terms and conditions of the Creative Commons Attribution (CC-BY) license (http://creativecommons.org/licenses/by/4.0/). 